\title{
DESIGNING ARCHITECTURAL PROCEDURE FOR HOUSE PARTICULARLY FOR CHILDREN
}

\author{
Fatemeh Mohammadian \\ Department of Architecture, Tabriz Branch, Islamic Azad University, Tabriz, Iran \\ f.mohammadian.arch@gmail.com \\ Hassan Sattari Sarbangholi \\ Department of Architecture, Tabriz Branch, Islamic Azad University, Tabriz, Iran \\ sattari@iaut.ac.ir
}

\begin{abstract}
Children cortical most important for future prosperity and social dynamics that make up the country. Architectural design Successful environment for children requires taking into account the criteria and Indexes particular, this class is special. In the present study focuses on increasing creativity children tried to theoretical studies in the field architectural design children will be achieved. The goal of this research architectural design Social and institutional focus as children house in the event of increasing creativity children. Architectural design process that uses two physical planning and architecture architectural design takes place hence in the physical planning architecture, design body design diagrams and charts to design, specify the required spaces, layout and communication spaces, diversity and quality of space, flexibility and fluidity of space and form design, it is predicted, then step architectural design Takes place, in this study the process architectural design for children there will be a special home, descriptive and analytical methodology for collecting data library method is then based on the analysis of information and related charts are plotted diagram based on the conducted analysis and alternatives based on the factors affecting the architectural design Special children's home has been suggested that in line with the idea architectural designing format of architectural design Special children's homes, alternative and superior architectural design ideas will be selected. The results can be child-centered design or architectural design that most users of space, children are utilized.
\end{abstract}

Keywords: architecture fabric, architectural design, children house, increasing creativity

\section{INTRODUCTION}

In today's cities, with little reflection on human settlement environment and especially children due to the fact that the time has come for children's attention and emphasis on architecture. Architectural ideas and new designs should be able to meet the needs of today's children is physically spirit. Evidence-based research to support the development of creative skills develop in children and adolescents, flexible use of space and time, the availability of suitable materials, activities outside the classroom, it seems logical game based on independence (Davies, Collier 2013) research indicated that children's creativity "will depend on the strength of their imagination," imagination is the most important factor in promoting children's creativity (Shafaei and Madani, 2010). In terms of Sigmund Freud should be a source of creativity in childhood experiences it is therefore necessary to find a person in the early stages of child development, fosters creativity he considered (Noghrekar et al., 2009). Creativity is the interaction between talents. Creativity with a focus on the environment, this axis as the most important factor is the formation of creative ideas. (Bisadi, Hosseini, 2012) in recent years in the field of creativity of children and students does a lot of research in the field of emotional-cognitive and educational issues. Unfortunately in the field of architecture and the role of architectural space less attention has been paid in 
nurturing creativity (Mahdavinezhad and Silvayeh, 2013). With regard to the process of learning in early childhood, playing the best communications natural environment is the best place of learning for children.

Recognizes the child's talent and creativity increases his potential. (Faizi, Karimi, Azari, 2012) With regard to growth, activation, promotion of creativity in children is very important. In order to improve creativity, some ways of encouraging children's minds to new thinking and develop creativity. One of these methods, the impact of natural or synthetic environments for children is increasing creativity (Acar, 2014) without a doubt, any development that occurs in contemporary art to artistic phenomena can say that art is essentially the same as creativity. The emergence of artistic creativity as creativity in other fields of science and education need help and involvement of some subjective and dependent on environmental factors. architectural design process considering the circumstances of architectural design in mind, the conditions and the architectural design of its own needs, in the process of architectural design is the same with respect to the project architectural design to suit to be asked employers and purpose and idea of architecture, items of categories and priorities, and then consider conditions such as climate, architectural design to architectural design, site design and texture desired area, access to him architectural design project takes place determined to architectural design goals, ways to achieve these objectives design comes in pre-measured and evaluated welcomed the plan, after the operation of the scheme takes place, the strengths and weaknesses plan No anticipated and checked up after the project architecture, the weaknesses of the design minimized, architectural design, especially children need to know the child and the child's use of space in architectural design and children spaces for children with attention to the child's size, scale and children's furniture, attractive and inviting spaces for children takes place.

\begin{tabular}{|c|c|c|c|}
\hline Date & Author & Title & Conclusion \\
\hline 1993 & $\begin{array}{l}\text { Tourense, Translated by } \\
\text { Hassan Ghasemzadeh }\end{array}$ & $\begin{array}{l}\text { They nurture creative talents } \\
\text { and skills, and ways }\end{array}$ & $\begin{array}{l}\text { Knowledge and understanding of } \\
\text { how to develop their talents - } \\
\text { Movers creativity - creativity } \\
\text { growth from an early age }\end{array}$ \\
\hline 1997 & $\begin{array}{c}\text { Translated } \\
\text { byNematollahYarahmadi }\end{array}$ & $\begin{array}{l}\text { Behavior (building and } \\
\text { guiding children up to } 10 \\
\text { years old).Leading } \\
\text { Publications } \\
\end{array}$ & $\begin{array}{l}\text { Understand the characteristics of } \\
\text { the dominant character in their } \\
\text { childhood and childhood to the } \\
\text { age of } 10 \text { years takes place }\end{array}$ \\
\hline 2010 & $\begin{array}{l}\text { Minu Shafaei, } \\
\text { Ramin Madani }\end{array}$ & $\begin{array}{l}\text { Design principles of } \\
\text { educational facilities based on } \\
\text { creativity, Journal of } \\
\text { Technology Education, fourth, } \\
\text { Volume 4, Issue 3, } \\
\text { Spring 2010 }\end{array}$ & $\begin{array}{l}\text { - Physical environmental design of } \\
\text { educational facilities based on the } \\
\text { creativity } \\
\text {-In Considering the factors } \\
\text { stimulating creativity in the design } \\
\text { space }\end{array}$ \\
\hline 2013 & $\begin{array}{c}\text { Mahdavinejad, GH, Siluayh } \\
\text { Sonia }\end{array}$ & $\begin{array}{l}\text { The impact of the arts on } \\
\text { student creativity, innovation } \\
\text { training Quarterly, Issue 48, } \\
\text { Winter 2014 }\end{array}$ & $\begin{array}{l}\text { - Creativity with a focus on } \\
\text { creative person - creativity with a } \\
\text { focus on creative mental process } \\
\text { with a focus on the environment } \\
\text { creative creativity-focused } \\
\text { operation with a focus on the } \\
\text { environment as the most important } \\
\text { factor is the formation of creative } \\
\text { ideas. }\end{array}$ \\
\hline
\end{tabular}




\begin{tabular}{|c|c|c|c|}
\hline 2000 & $\begin{array}{c}\text { Perkins, broad } \\
\text { Ford. }\end{array}$ & \begin{tabular}{|c|} 
Type and quality of the \\
building for secondary school
\end{tabular} & $\begin{array}{l}\text { - Designed to take advantage of its } \\
\text { functional structure in accordance } \\
\text { with its function of building fabric }\end{array}$ \\
\hline 2012 & Rabia Cigdem Cavdar. & \begin{tabular}{|c|}
$\begin{array}{c}\text { The Impact of Architectural } \\
\text { Education on Children }\end{array}$ \\
\end{tabular} & $\begin{array}{l}\text { Training \& educational } \\
\text { architecture as a design always } \\
\text { encourages creativity }\end{array}$ \\
\hline 2013 & Habibe Acar. & \begin{tabular}{|l|} 
Learning Environments for \\
Children in Outdoor Spaces \\
\end{tabular} & $\begin{array}{l}\text { - Open spaces and routes and } \\
\text { curiosity for children movement } \\
\text { of the actuator movement in open } \\
\text { spaces to explore surroundings } \\
\text { surroundings experienced -child } \\
\text { learns deals }\end{array}$ \\
\hline 2013 & $\begin{array}{c}\text { Dan Davies, Divya Jindal- } \\
\text { Snape, Chris Collier }\end{array}$ & Thinking skills and creativity & $\begin{array}{l}\text { Creating profit and applying } \\
\text { creative thinking, creative thinking } \\
\text { and creative direct -rank }\end{array}$ \\
\hline 2013 & Faizi, Karimi, Azari & $\begin{array}{l}\text { Of residential space designed } \\
\text { to promote children's } \\
\text { creativity (designing creative } \\
\text { Pedagogies through the use of } \\
\text { ICT in secondary education) }\end{array}$ & $\begin{array}{l}\text { - Use natural herbs to stimulate } \\
\text { creativity in residential areas -Use } \\
\text { of light to stimulate creativity -use } \\
\text { of color as creative agents }\end{array}$ \\
\hline
\end{tabular}

\section{BACKGROUND ON RESEARCH THEORIES}

SOME BACKGROUND RESEARCH THEORY:

Source table according to sources cited by the author

SOME OF THE RECORDS OF ARCHITECTURAL DESIGN:

Table 2.1. Examples of architecture museums and centers of children's creativity

\begin{tabular}{|c|c|c|c|c|}
\hline Date & $\begin{array}{c}\text { Name } \\
\text { architect }\end{array}$ & City / Country & Architectural documents & \multicolumn{1}{c|}{ Points to consider } \\
\hline & & www.archdaily.com & $\begin{array}{l}\text { Children interact with each other } \\
\text { through fun activities to increase } \\
\text { children's awareness. } \\
\text { Designed aspects. } \\
\text { The structural design of a cantilever roof } \\
\text { with 8 meters high, like a big umbrella } \\
\text { to provide shade and protection from } \\
\text { rain. }\end{array}$ \\
\hline $2007-$ & $\begin{array}{c}24 \mathrm{H}> \\
\text { architecture }\end{array}$ & $\begin{array}{c}\text { Mountain fertilizer } \\
\text { island in the Gulf } \\
\text { of Thailand }\end{array}$ & & \\
\hline
\end{tabular}

\footnotetext{
${ }^{1}$ Beck, et al Laboratory 2 Design guide, Architecture press Building type basic for elementary and secondary schools
} 


\begin{tabular}{|c|c|c|c|c|}
\hline 2010 & $\begin{array}{c}\text { The kubala } \\
\text { washatko } \\
\text { architects }\end{array}$ & Madison /Vskansyn & www.archdaily.com & $\begin{array}{l}\text { The architectural design of the museum } \\
\text { of local natural materials and colors that } \\
\text { somehow raise the quality of the air } \\
\text { inside the museum as well as attending a } \\
\text { ordinary green space in the induction of } \\
\text { user. } \\
\text { Sustainable design using green roof and } \\
\text { photovoltaic panels for electricity. }\end{array}$ \\
\hline 2011 & $\begin{array}{l}\text { Work Ac } \\
\text { Architecture }\end{array}$ & $\begin{array}{l}\text { New York / United } \\
\text { States of America }\end{array}$ & www.archdaily.com & $\begin{array}{l}\text { The museum is designed to encourage } \\
\text { more kids to the arts and learning, a } \\
\text { place where kids where their works and } \\
\text { exhibit them at the same time. Water for } \\
\text { hand-washing cycle to be modified and } \\
\text { tailored to different age groups. }\end{array}$ \\
\hline- & $\begin{array}{c}\text { Zeraf } \\
\text { architecture } \\
\text { studio }\end{array}$ & Taipei / Taiwan. & www.archdaily.com & $\begin{array}{l}\text { Children's museum is designed in two } \\
\text { separate floors of the main museum and } \\
\text { around the site in relation to the park. } \\
\text { Box Toys sink embedded in the floor } \\
\text { area so that children are encouraged to } \\
\text { pass out of the museum and park. }\end{array}$ \\
\hline - & $\begin{array}{l}\text { Krueck \& } \\
\text { Sexton } \\
\text { Architects }\end{array}$ & Illinois / Chicago & www.archdaily.com & $\begin{array}{l}\text { Its contact between the play and learn at } \\
\text { the museum galleries for spiral ramp at } \\
\text { floor level. } \\
\text { There atrium over the entire surface of } \\
\text { galleries to display and provide physical } \\
\text { activity for children. }\end{array}$ \\
\hline
\end{tabular}

And analysis of the samples examined:

Diagram 1-33 index component in architectural design spaces for children

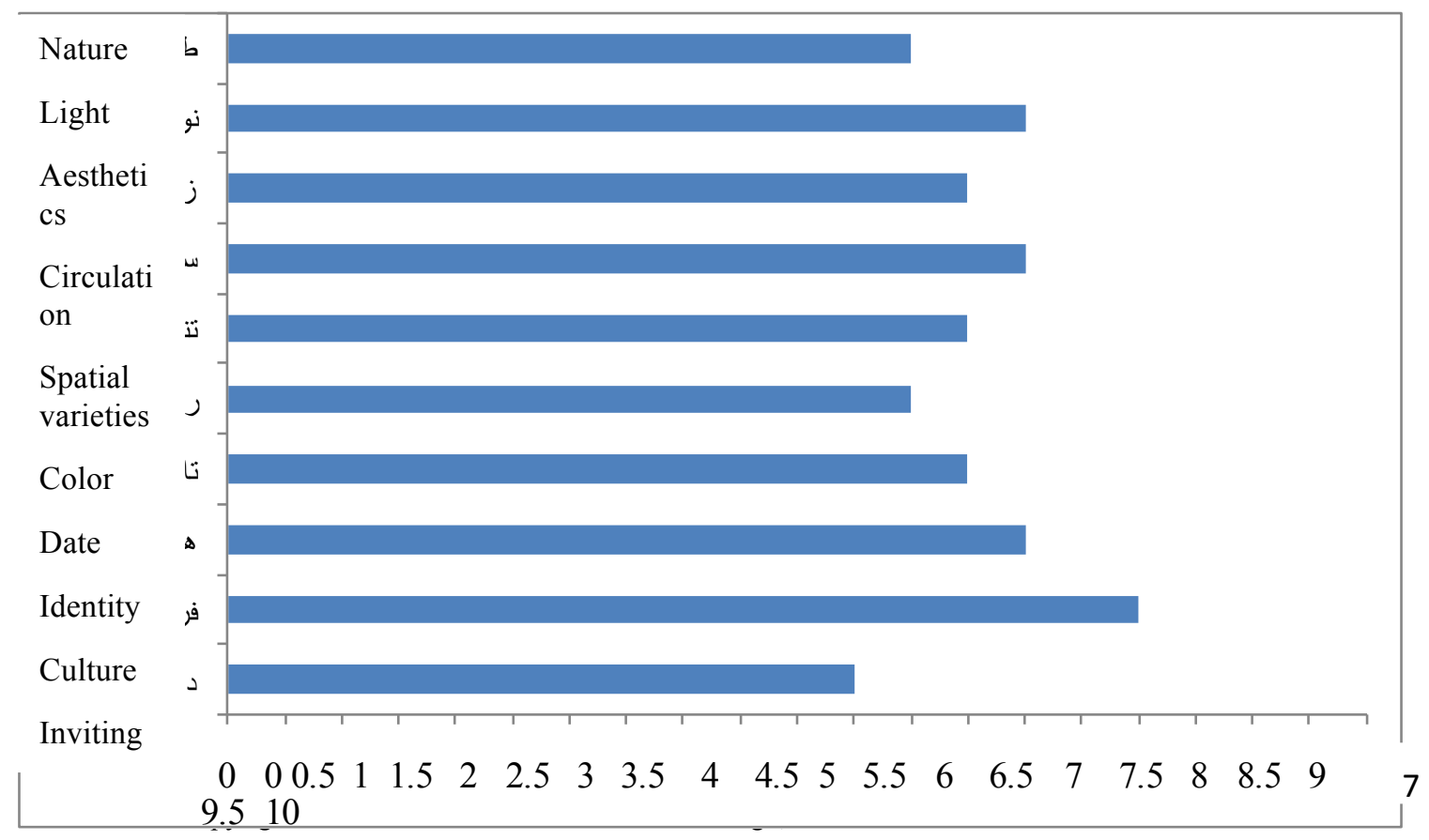


Reference: author

Figure 2.3 the components of the index upward trend in architectural design spaces for children

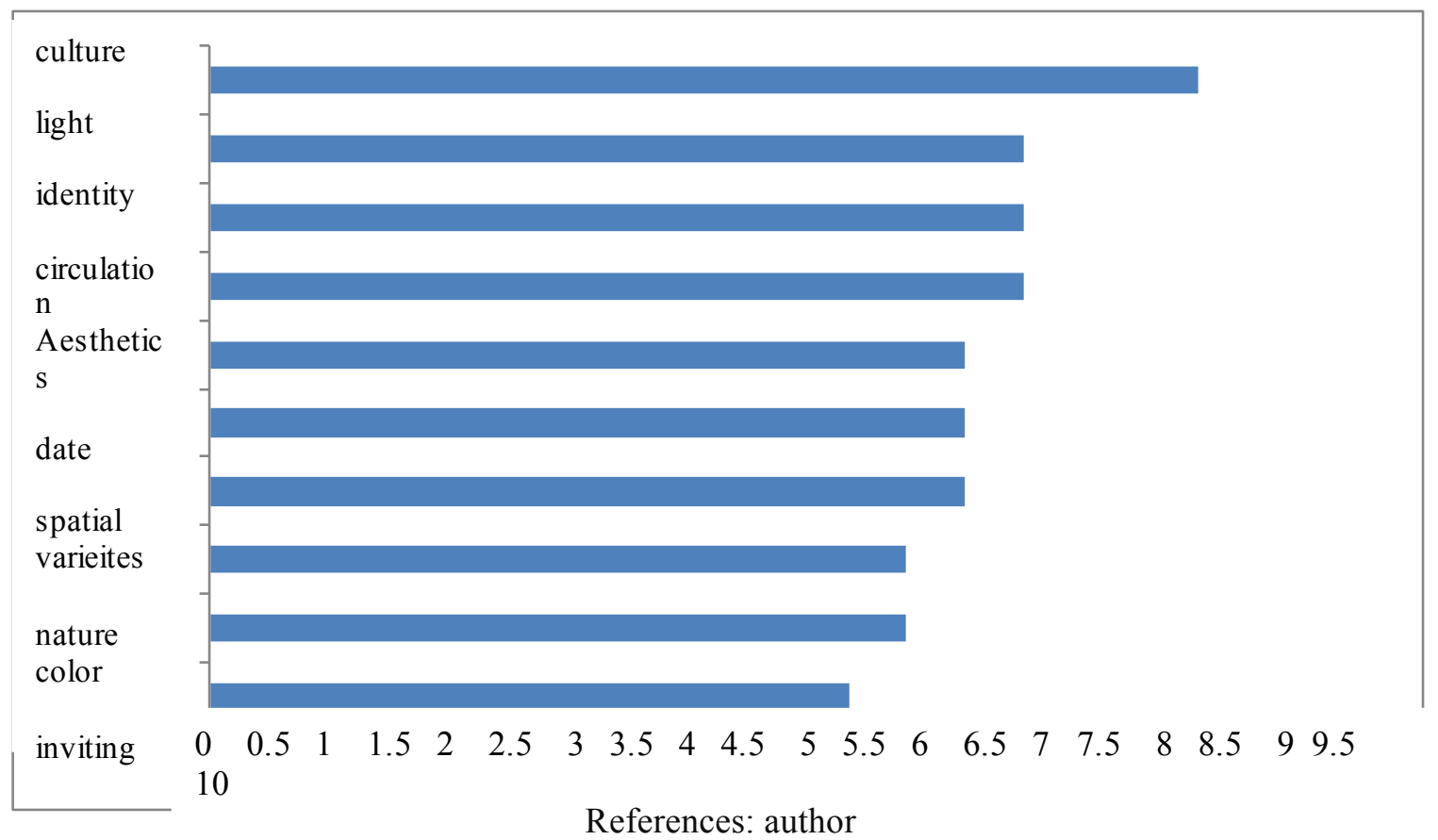

THE ACTIVITIES WITHIN THE PROJECT:

Table 4.1 Examine the inner workings Plan

\begin{tabular}{|c|c|}
\hline Year & 1994 \\
\hline Author & Nazarinezhad, H. Aylin, Hart, B. \\
\hline Books (paper) & Pre-school education \\
\hline Source & Astan Quds Razavi, Second Edition \\
\hline Title & Indoor activity \\
\hline Design Pattern & $\begin{array}{l}\text { The lack of space limited by high walls and } \\
\text { divided by walls and counters the growth and } \\
\text { creativity of children is raised. Restrict minors } \\
\text { caused abnormalities in the child's character } \\
\text { and sense of doubt in him. The child will doubt } \\
\text { their abilities and sense of confidence and loses } \\
\text { its independence. } \\
\text { Each class requires a space that is empty of any } \\
\text { structural elements, outdoor use and has no } \\
\text { restrictions. } \\
\text { Each section can be large or small as needed, } \\
\text { and most of them employed in hours of } \\
\text { operation. It should be noted that the paths are } \\
\text { designed in such a way that it will not interrupt }\end{array}$ \\
\hline
\end{tabular}




\begin{tabular}{|c|c|c|c|c|}
\hline & & & $\begin{array}{l}\text { the space and the space shuttle in } \mathrm{sp} \\
\text { not come for free. } \\
\text { Partition model and the wall must b } \\
\text { the guys put a more intimate spaces } \\
\text { the same time the teacher saw the g } \\
\text { space is not blocked. }\end{array}$ & $\begin{array}{l}\text { ace does } \\
\text { and cozy at } \\
\text { uys in this }\end{array}$ \\
\hline $\begin{array}{l}\text { Classification of } \\
\text { Education }\end{array}$ & $\begin{array}{c}\text { Educational } \\
\text { materials related } \\
\text { to the activities of } \\
\text { teacher-made }\end{array}$ & $\begin{array}{c}\text { Educational } \\
\text { materials related } \\
\text { to self-help }\end{array}$ & $\begin{array}{l}\text { Educational materials for } \\
\text { discovery learning }\end{array}$ & \\
\hline & $\begin{array}{c}\text { Music } \\
\text { Story } \\
\text { Language } \\
\text { Special events }\end{array}$ & $\begin{array}{c}\text { Dress } \\
\text { resting } \\
\text { Go to the } \\
\text { bathroom } \\
\text { eat } \\
\text { Sort of room and } \\
\text { collect objects }\end{array}$ & $\begin{array}{c}\text { The cubes } \\
\text { The manual skills } \\
\text { Exploratory Arts section } \\
\text { The housework } \\
\text { The section on special interests }\end{array}$ & \\
\hline $\begin{array}{c}\text { Discovery learning } \\
\text { training materials } \\
\text { for indoor activities }\end{array}$ & $\begin{array}{c}\text { The Arts } \\
\text { Initiative: (the } \\
\text { crafts) }\end{array}$ & \begin{tabular}{|c} 
Housekeeping \\
section (section \\
bases imaginary)
\end{tabular} & $\begin{array}{l}\text { The cube (part of the game } \\
\text { collective) }\end{array}$ & \\
\hline & $\begin{array}{l}\text { In this section, } \\
\text { what is particular } \\
\text { useful for the large } \\
\text { table in the middle } \\
\text { of the room with } \\
\text { the tools needed } \\
\text { and categorized } \\
\text { for different } \\
\text { activities on it. }\end{array}$ & $\begin{array}{l}\text { To be able to } \\
\text { fully play the } \\
\text { role of their } \\
\text { children, the } \\
\text { housework as } \\
\text { much as possible } \\
\text { to be separated } \\
\text { from other parts } \\
\text { of commuting } \\
\text { accidents for } \\
\text { children in this } \\
\text { section will not } \\
\text { interrupt the } \\
\text { other children. } \\
\text { The } \\
\text { housekeeping } \\
\text { usually short } \\
\text { fences and walls } \\
\text { in the corner and } \\
\text { carrying it } \\
\text { separates the } \\
\text { room from the } \\
\text { rest. }\end{array}$ & \begin{tabular}{|l} 
An open space on the floor with \\
shelves carrying on one or both \\
sides of it. Based on the size and \\
shape of cubes on the shelves \\
instead charge of. Children can \\
shapes and sizes that are needed \\
for the building of their choice and \\
your imagination to reality.
\end{tabular} & \\
\hline
\end{tabular}

According to Hart, the author of the source table

\section{EVALUATION OF OUTDOOR ACTIVITIES:}

Table 5.1 Evaluation of activities outside the building 
The Turkish Online Journal of Design, Art and Communication - TOJDAC August 2016 Special Edition

\begin{tabular}{|c|c|c|c|c|}
\hline Year & Author & Books (paper) & Source & Investigation activities outside building \\
\hline 1994 & $\begin{array}{l}\text { Nazarinezhad, } \\
\text { H. Aylin, } \\
\text { Hart, B. }\end{array}$ & $\begin{array}{l}\text { Pre-school } \\
\text { education }\end{array}$ & $\begin{array}{c}\text { Astan Quds } \\
\text { Razavi, Second } \\
\text { Edition } 1994\end{array}$ & $\begin{array}{l}\text { Space and attention to the game including the most } \\
\text { important areas is essential because it can be said } \\
\text { that one of the attractions that brought the child at } \\
\text { the center of this play space (such as game). At least } \\
\text { half of the space should be exposed to the } \\
\text { sun. Meanwhile, in the free atmosphere of the game, } \\
\text { should be provided with devices that can provide } \\
\text { needed shade. So that the land must be divided into } \\
\text { different age groups for children with appropriate } \\
\text { means commensurate with the building, playground } \\
\text { equipment, landscaping and boundary characteristic } \\
\text { of such requirements, and they are almost } \\
\text { indistinguishable if the children can hear each } \\
\text { other's voices as well as each other see (Ayline et } \\
\text { al., 1994 ). }\end{array}$ \\
\hline & $\begin{array}{l}\text { Society for } \\
\text { the Protection } \\
\text { of the Rights } \\
\text { of the Child }\end{array}$ & $\begin{array}{c}\text { Convention on } \\
\text { the Rights of } \\
\text { the Child }\end{array}$ & $\begin{array}{l}\text { Publishers } \\
\text { Sorush and } \\
\text { UNICEF, } \\
\text { Tehran, First } \\
\text { Edition. }\end{array}$ & $\begin{array}{l}\text { In paragraph } 2 \text { of the International Covenant states } \\
\text { that it is necessary and appropriate spaces various } \\
\text { authorities provide for children to play. This place is } \\
\text { better to be near the children's place of residence } \\
\text { (Society for the Protection of the Rights of the } \\
\text { Child, 1997). }\end{array}$ \\
\hline
\end{tabular}

According to Hart, the author of the source table

SPACE CHARACTERISTICS AND LEVELS OF PLAY:

Table 6-1 Study activities outside the building

\begin{tabular}{|c|c|c|c|c|}
\hline Year & Author & $\begin{array}{l}\text { Books } \\
\text { (paper) }\end{array}$ & Source & Characteristics and levels of play space \\
\hline 2004 & $\begin{array}{c}\text { Ayda } \\
\text { Izadpanah } \\
\text { Jahromi }\end{array}$ & $\begin{array}{l}\text { Child } \\
\text { play } \\
\text { city }\end{array}$ & $\begin{array}{c}\text { Page } \\
27 .\end{array}$ & $\begin{array}{l}\text { According to the opinion of psychologists "game" is an activity when the } \\
\text { five properties are met: } \\
\text { Do not intrinsically and motivate. } \\
\text { Participate in it freely and not forced. } \\
\text { It is actively participating in such a manner. } \\
\text { Is enjoyable and fun. } \\
\text { Levels of pretense and imitation, and in this way the child employ } \\
\text { the power of your imagination (Izadpanah Jahromi, 2004). }\end{array}$ \\
\hline
\end{tabular}

According to the author Ilzadpanahi Jahromy

VIEW SPACE FOR DIFFERENT AGE GROUPS:

Table 7.1 Specifications space for different age groups

\begin{tabular}{|c|c|}
\hline Year & 2004 \\
\hline Writer & Izadpanah Jahromi Aida \\
\hline
\end{tabular}

Submit Date: 23.06.2016, Acceptance Date: 25.07.2016, DOI NO: 10.7456/1060AGSE/034

Copyright (C) The Turkish Online Journal of Design, Art and Communication 


\begin{tabular}{|c|c|}
\hline $\begin{array}{l}\text { Books } \\
\text { (paper) }\end{array}$ & Child play city \\
\hline Source & Page 27 \\
\hline Title & View space for different age groups \\
\hline $\begin{array}{l}\text { Profile } \\
\text { playground } \\
\text { for the age } \\
\text { group } 0-3 \\
\text { years }\end{array}$ & $\begin{array}{l}\text { Activity: ball games, fantasy games, according to knowing things, running and walking. } \\
\text { Equipment bags of sand, place flowers game, small game devices, and portable devices. } \\
\text { Location: indoors or outdoors, lawn work or the floor and without stairs and dangerous angle. } \\
\text { Minimum Space: about one square meters for each child. }\end{array}$ \\
\hline $\begin{array}{l}\text { View the } \\
6 \text {-year-old } \\
\text { group } \\
\text { match age } \\
4\end{array}$ & $\begin{array}{l}\text { Activity: ball, running } \\
\text { Equipment: Goods for land-based game full of sand, creating a solid ground for painting and } \\
\text { skating. } \\
\text { Location: land to set up tents open and closed positions, lawn work or the floor without stairs } \\
\text { or dangerous angle. } \\
\text { Minimum space: about } 2 \text { square meters for each child. }\end{array}$ \\
\hline $\begin{array}{l}\text { Profile } \\
\text { playground } \\
\text { Group age } \\
\text { range } 7-11 \\
\text { year }\end{array}$ & $\begin{array}{l}\text { Activities, ball games, and free games and fields of grass or the floor. } \\
\text { Equipment: Pathways to sports games, building games, workshops for foster artistic } \\
\text { creativity. } \\
\text { Location: Outdoor, Lawn, or the flooring. } \\
\text { Minimum space: about } 3 \text { square meters for each child. }\end{array}$ \\
\hline
\end{tabular}

B adopted from author: Izadpanah Jahromi

\section{SPACE ADVENTURE GAME:}

Table 2.1 Space adventure game

\begin{tabular}{|c|c|}
\hline Year & 2004 \\
\hline the writer & Jean Piaget \\
\hline $\begin{array}{l}\text { Books } \\
\text { (paper) }\end{array}$ & Games and emotions of childhood \\
\hline Source & London, 383, pp. 146-150. \\
\hline Title & View space for different age groups \\
\hline $\begin{array}{l}\text { Playground } \\
\text { of adventure }\end{array}$ & $\begin{array}{l}\text { Earth adventurer, who prepared the earth closed with variable dimensions, some objects } \\
\text { and various building materials and the children had been left in it so they can use your } \\
\text { creativity with the construction of cottages, they strengthen the gardening and ... . } \\
\text { This type of game is just a small hut or shelter against rain is needed that can be used as a } \\
\text { warehouse for the ongoing work of the seasons be considered if it can be place with a } \\
\text { minimum area of } 100 \text { square meters where was built. Children of such lands to build and } \\
\text { create new forms and arrangements that called for flexibility with their cognitive, social, } \\
\text { and physical growth of children in a very effective medium. }\end{array}$ \\
\hline $\begin{array}{l}\text { Green space } \\
\text { adventure } \\
\text { game }\end{array}$ & $\begin{array}{l}\text { In these spaces, natural areas informally with their size, diversity and variability, creativity } \\
\text { and knowledge of local natural conditions are favorable. The lack of clear structures and all } \\
\text { of these fields, to develop children's imagination and imagine that. } \\
\text { Game environment in such a situation must flow from one environment to another in an } \\
\text { endless manner and as simple as encouraging children's creativity flourish. The key to } \\
\text { success in such places, the participation of users in the design process. This land could be } \\
\text { multi-purpose building two or three rooms for socio-cultural activities would be beneficial. }\end{array}$ \\
\hline
\end{tabular}

According to Jean Piaget by the author

\section{CLASSIFICATION RECREATIONAL ACTIVITIES FOR CHILDREN 6 TO 12 YEARS OLD:}


Table 2.2 Classification recreational activities for children 6 to 12 years old

\begin{tabular}{|c|c|c|}
\hline Year & \multicolumn{2}{|l|}{1994} \\
\hline Writer & \multicolumn{2}{|c|}{ Consulting Engineers environmental tests } \\
\hline Books (paper) & \multicolumn{2}{|c|}{ Principles and criteria for designing urban parks } \\
\hline Source & \multicolumn{2}{|c|}{ Department of Parks and green space. } \\
\hline Title & \multicolumn{2}{|c|}{ Classification recreational activities for children 6 to 12 years old } \\
\hline Classification Activities & Facilities and activities elements & Type of activity \\
\hline \multirow{6}{*}{$\begin{array}{c}\text { Presence in communities } \\
\text { and nature } \\
\text { Creativity, visualization }\end{array}$} & $\begin{array}{l}\text { Walls and the flooring to play and write in } \\
\text { a closed area with tables and chairs, arbor. }\end{array}$ & $\begin{array}{l}\text { Collaboration, knowledge with } \\
\text { others, plays a role. }\end{array}$ \\
\hline & $\begin{array}{l}\text { Lunch - coffee, library, open space with } \\
\text { benches. }\end{array}$ & Study and relax. \\
\hline & Dramatic free space. & $\begin{array}{l}\text { Attend theater (as an actor and } \\
\text { spectator). }\end{array}$ \\
\hline & $\begin{array}{l}\text { Proscenium, small house, ship and train, } \\
\text { jeep. }\end{array}$ & Story alive. \\
\hline & $\begin{array}{l}\text { Circus - theater, puppetry, and children's } \\
\text { theater. }\end{array}$ & Watching the outdoor show. \\
\hline & $\begin{array}{c}\text { Tools for painting, workshops, } \\
\text { warehouses, exhibition materials. }\end{array}$ & Visual and artistic activities. \\
\hline \multirow[b]{5}{*}{ Physical and motor } & stairs, different levels of & Jumping up and down, dangling. \\
\hline & Lake dock jet stream. & Water play. \\
\hline & Slides - inclined surfaces - height. & Glide, Welter. \\
\hline & $\begin{array}{l}\text { Swing ropes, nets, axes fixed and mobile } \\
\text { balance for mobile bridges, carousels. }\end{array}$ & $\begin{array}{l}\text { Suspended in the air, rocking } \\
\text { motion, balancing. }\end{array}$ \\
\hline & Volumes of shape, pipe tunnel labyrinth. & $\begin{array}{c}\text { Running- discover - hidden and } \\
\text { revealed. }\end{array}$ \\
\hline
\end{tabular}

Consulting Engineers environmental tests by author

PHYSICAL PLANNING ARCHITECTURE

Diagram 1- Architectural fabric planning

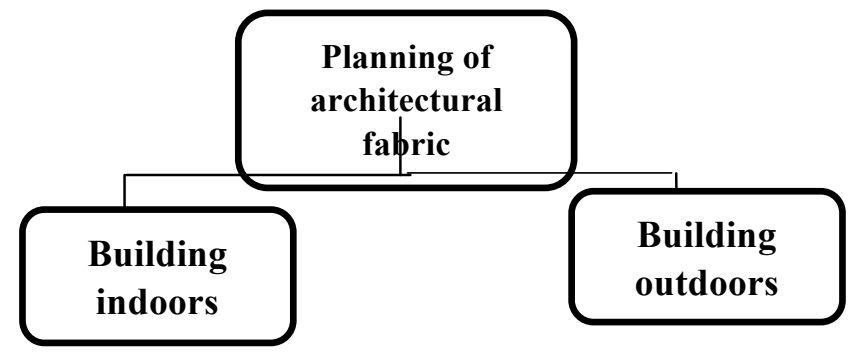

\section{SAMPLE OF OUTDOORS IN COLLECTION}

Diagram 1-1 diagram of sample of outdoors in collection

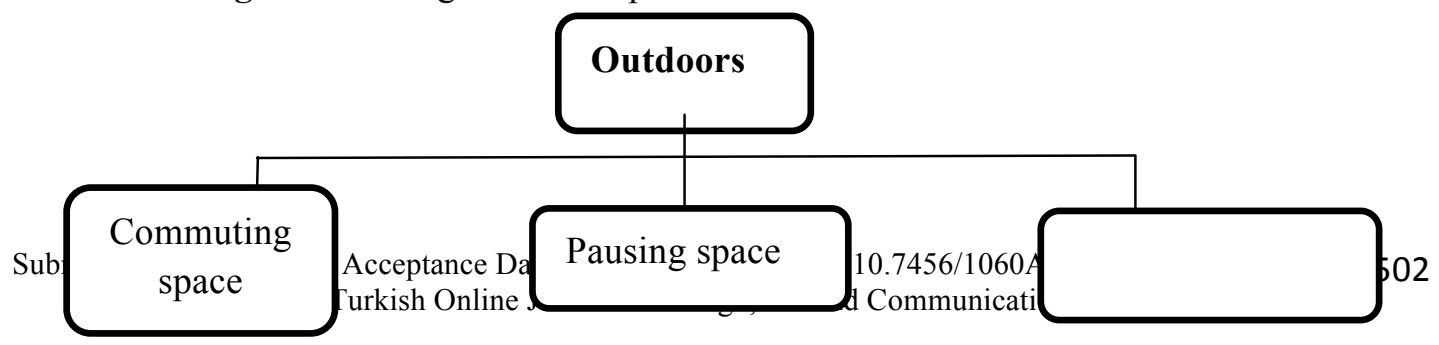



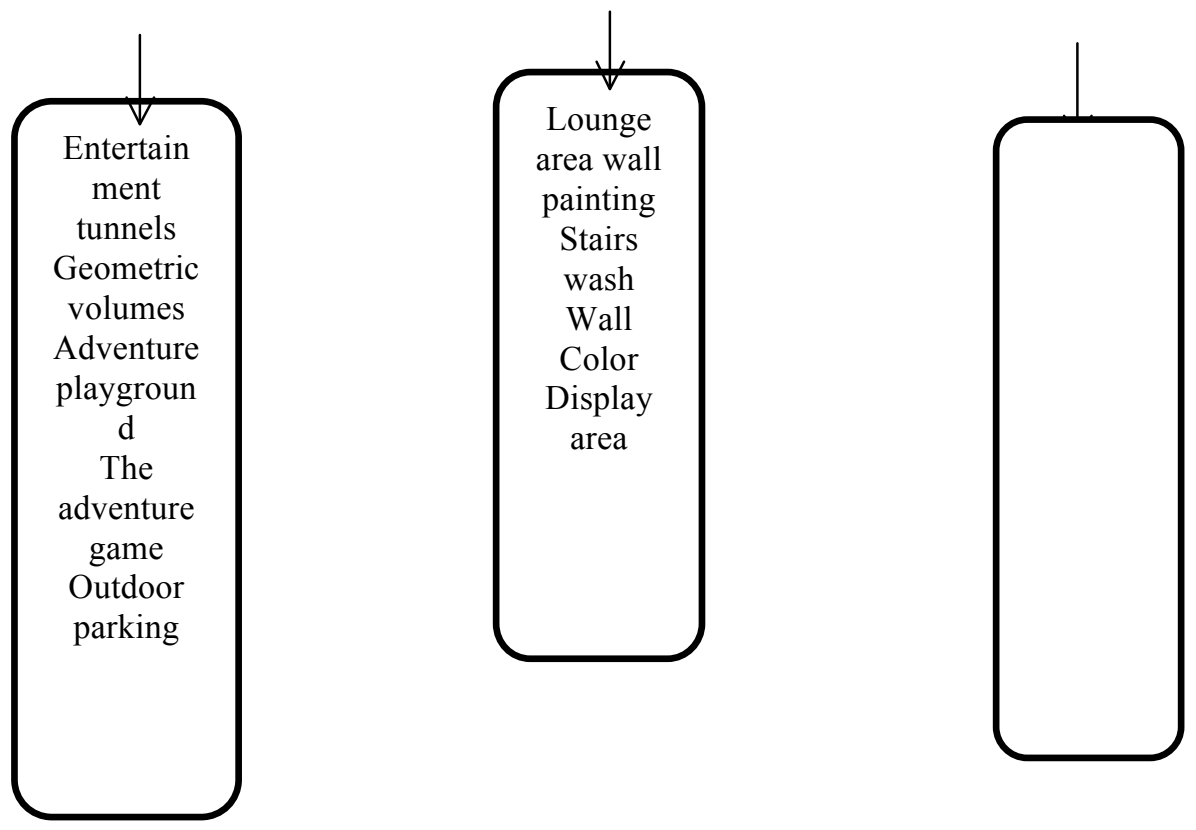

References: author

\section{DIAGRAM OF INDOORS SPACES}

Diagram 1-2: indoor spaces of collection

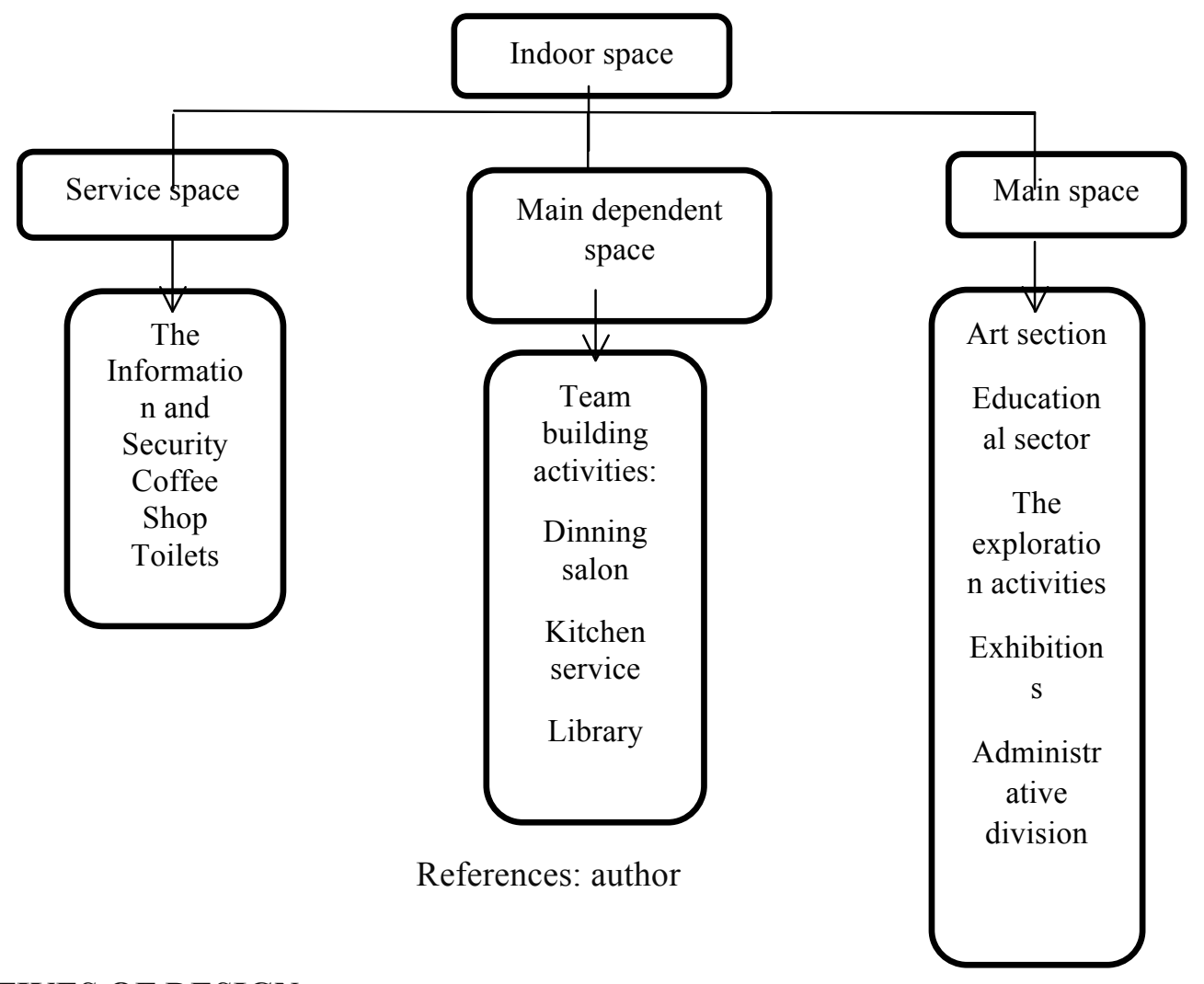

\section{- ALTERNATIVES OF DESIGN}


Alternative No. 1

\begin{tabular}{|l|l|}
\hline \multicolumn{2}{|c|}{ Features } \\
\hline Additional sections form a center and can be designed for specific spaces
\end{tabular}

Alternative 2.

Reference: author 


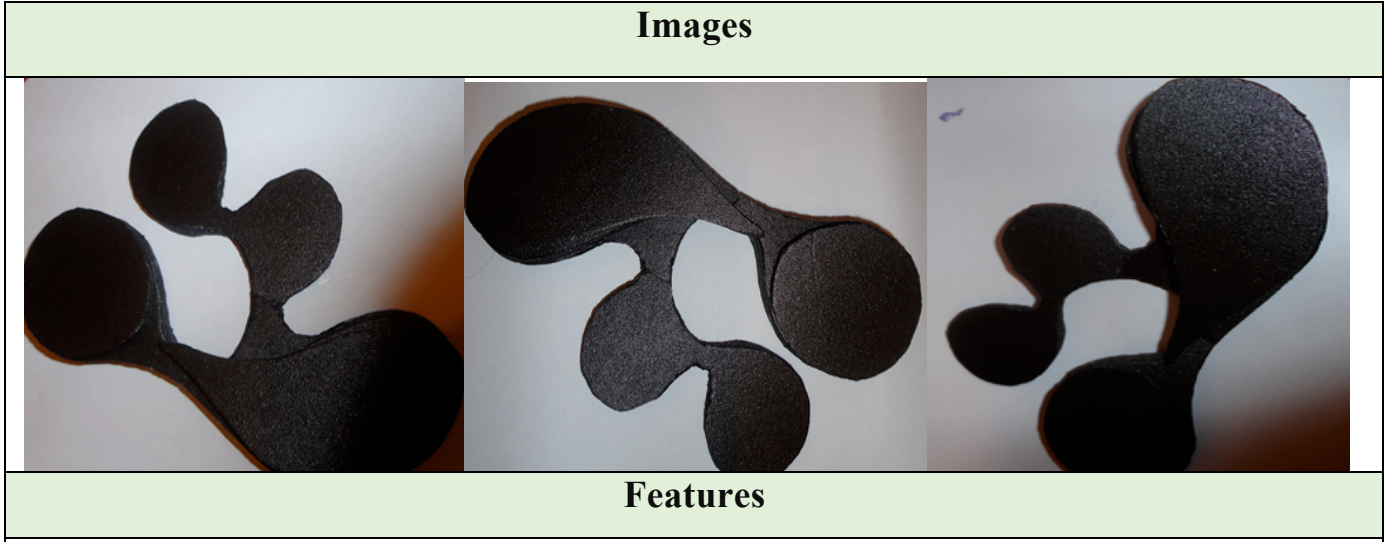

Children atmosphere using soft lines and curves and form Mntf-

Taking advantage of children's creativity in design concept form set

Design spaces dedicated to galleries to display works of children

\begin{tabular}{|l|l|}
\hline \multicolumn{1}{|c|}{ Defects of design } & \multicolumn{1}{c|}{ Advantages of design } \\
\hline $\begin{array}{l}\text { Lack of ease of implementation of the } \\
\text { plan }\end{array}$ & $\begin{array}{l}\text { Fitness series form with function } \\
\text { The need for skilled workers to run }\end{array}$ \\
$\begin{array}{l}\text { Costly implementical areas } \\
\text { Time on the implementation of the plan }\end{array}$ & \\
& \\
& \\
\hline
\end{tabular}

\section{SELECTING THE BEST ALTERNATIVE}

\begin{tabular}{|c|c|c|}
\hline Alternatives & Alternative 1 & Alternative 2 \\
\hline & \\
& & \\
\hline economy & $\checkmark$ & \\
\hline form & - & $\checkmark$ \\
\hline Conception & - & $\checkmark$ \\
\hline Performance & $\checkmark$ & $\checkmark$ \\
\hline $\begin{array}{c}\text { Proper movement } \\
\text { circulation }\end{array}$ & & \\
\hline
\end{tabular}




\begin{tabular}{|c|c|c|}
\hline View & $\checkmark$ & $\checkmark$ \\
\hline Landscape & $\checkmark$ & $\checkmark$ \\
\hline beauty & $\checkmark$ & $\checkmark$ \\
\hline $\begin{array}{c}\text { Compatibility with the } \\
\text { surrounding tissue } \\
\text { form }\end{array}$ & $\checkmark$ & $\checkmark$ \\
\hline $\begin{array}{c}\text { Located right on the } \\
\text { site }\end{array}$ & $\checkmark$ & - \\
\hline $\begin{array}{c}\text { Growth potential } \\
\text { Due to the climate }\end{array}$ & - & $\checkmark$ \\
\hline $\begin{array}{c}\text { According to the } \\
\text { concepts of creativity }\end{array}$ & & \\
\hline Total Points & & $\checkmark$ \\
\hline
\end{tabular}

Refenrece: author

\section{-DESIGN PROCEDURE}

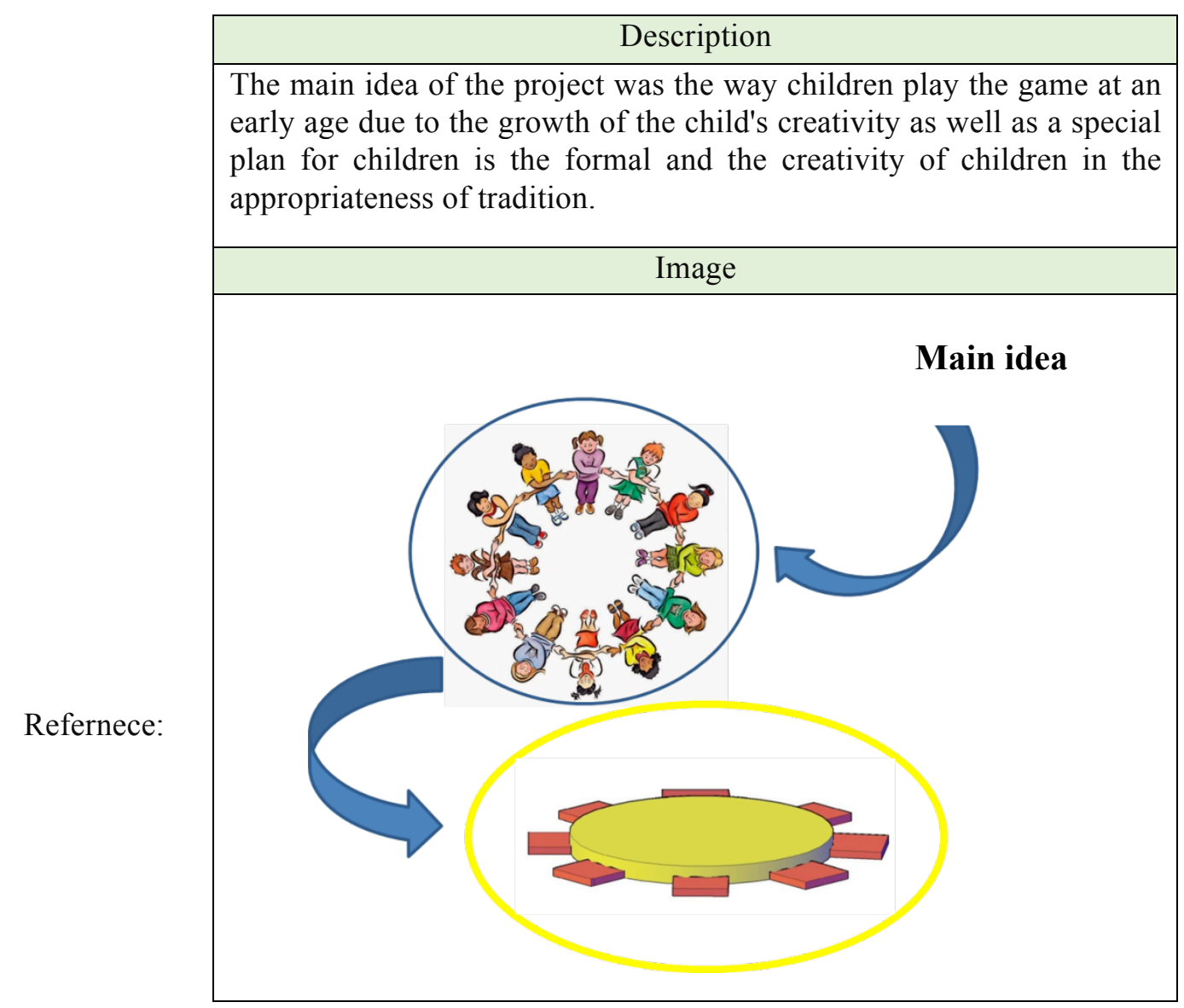

\section{SUGGESTED DESIGN FOR CHILDREN HOUSE}


-Suggested design for children house

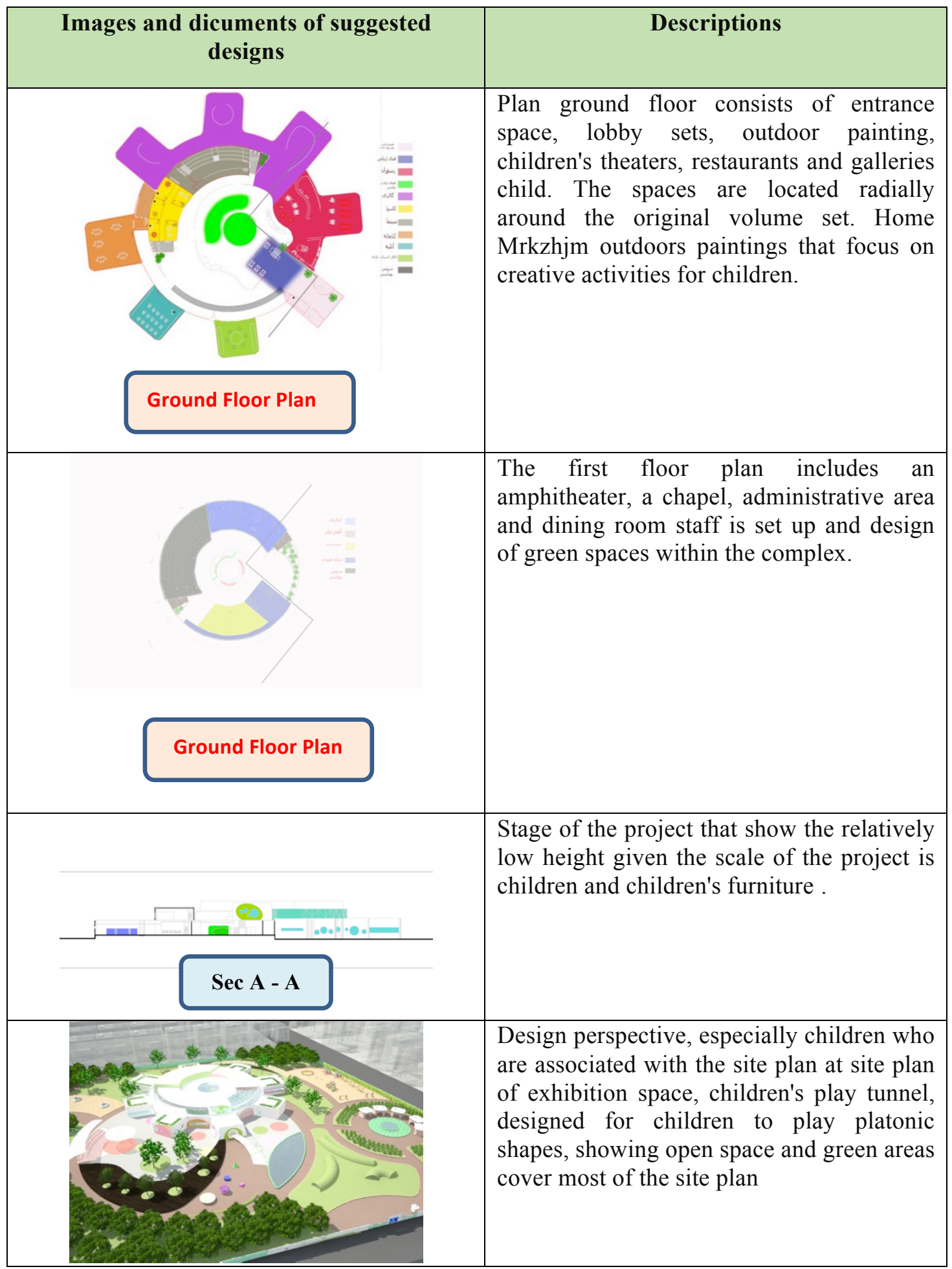




\begin{tabular}{|c|c|}
\hline 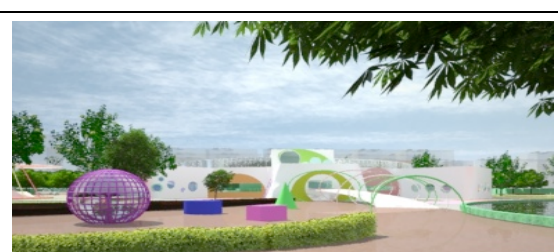 & $\begin{array}{l}\text { In this part of the site for the Platonic solids } \\
\text { collection is designed and intended for } \\
\text { children is that children can see and touch } \\
\text { the volumes closely with them to the game } \\
\text { that this way of creativity in children house }\end{array}$ \\
\hline$\frac{1}{8}$ & $\begin{array}{l}\text { Input using a soft curved lines and is } \\
\text { designed to move and inviting sense of } \\
\text { rhythm and repetition to induce a } \\
\text { form. Flooring designed specifically for } \\
\text { children, along with enjoying the lively } \\
\text { colors and childlike using a circular form, } \\
\text { space for togetherness and a sense of } \\
\text { collective game on the child. }\end{array}$ \\
\hline & $\begin{array}{l}\text { Show design space and an outdoor theater } \\
\text { for children in the natural environment of } \\
\text { the site, enabling performance in the natural } \\
\text { environment that provides children a } \\
\text { childish display space is open and makes } \\
\text { sense of excitement and enthusiasm for } \\
\text { children to run and watch the natural } \\
\text { environment sustains a relationship with the } \\
\text { surrounding natural environment. }\end{array}$ \\
\hline 1 & $\begin{array}{l}\text { Children's play area with games designed } \\
\text { furniture, play equipment, children's play } \\
\text { equipment (slides, swings, etc.) space for } \\
\text { play and entertainment and children are } \\
\text { together and enjoy the type and manner for } \\
\text { children, causing your child's creativity }\end{array}$ \\
\hline 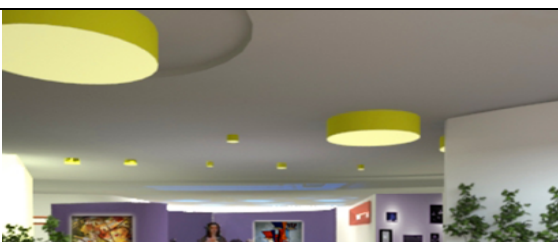 & $\begin{array}{l}\text { Children's drawings and art space designed } \\
\text { to show the effects of child growth in this } \\
\text { space makes sense to encourage children's } \\
\text { artistic talent and competitive exhibition of } \\
\text { children's children, and draw }\end{array}$ \\
\hline
\end{tabular}




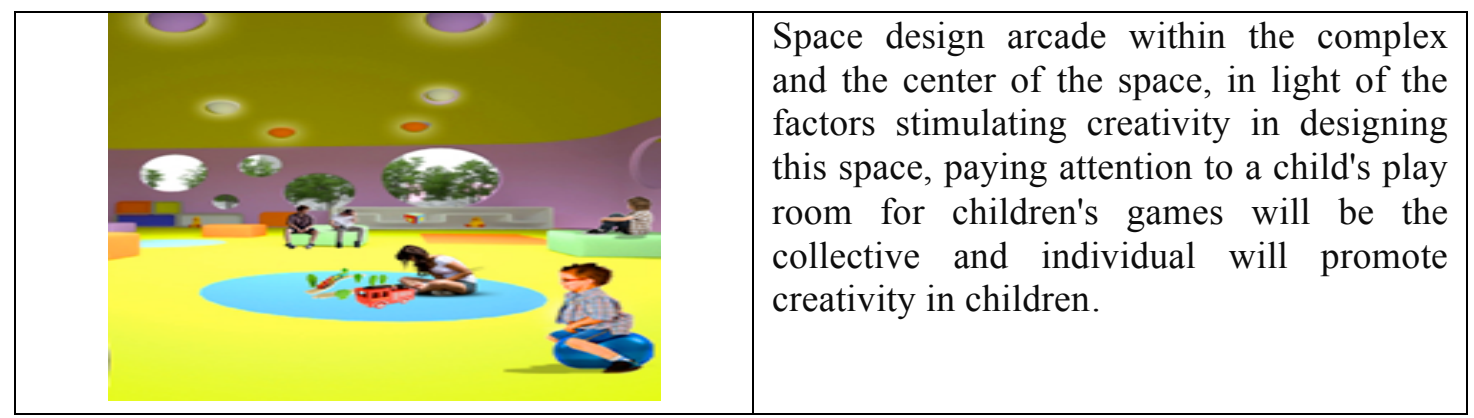

\section{CONCLUSION}

Given that the most important stage of life, from childhood to the formation of human character, spaces designed for children with mental and physical characteristics of children's knowledge, understanding children's needs required architectural spaces, by analyzing examples of architecture children the spaces of childhood by using components such as color, scale and children's furniture, a variety of spaces, inviting and readability spaces, the design of circulation, access suitable for children with the architectural design galleries and studios child, play spaces indoor and, children's library, children's theaters enjoying a theatrical art activities, storytelling to promote children's creativity. The results can be child-centered design or architectural design that most users of space, children are utilized.

\section{REFERENCES}

Izadpanah Jahromi - 2004, the principles and criteria for planning and design of play spaces, Tehran: Publication of municipalities

H. Ahmadi., Sh. S. Jamali Yani., 2009, developmental psychology, publications Foruzesh.

Ahmadvand M. 2002, the psychology of the game, Tehran Payam Noor University Press, pp. 8-16.

Aspadak, b, early childhood education, pp. 273-274.

The importance of play and cognitive development of children's creativity, development of educational technology, (4) 16, pp. 7 and 8.

T. Amayeli., H. Ghasemzadeh. And p. Azimi 1996, the blossoming of creativity of children, Tehran: Publication Donyayeno, p. 78.

Pvrjfr, M, D., Mahmoud, e. And Alizadeh, a., Analysis of the controversial children's creativity in the design of urban spaces and landscaping with an emphasis on creativity and children's play areas, structural design, urban management, Issue 25, Spring and Summer 2010, page 82-63.

Hassan Beyglu, B .., 2001, developmental psychology, Tehran: Saramad Sorush, pp. 7-9.

Hosseini, 2011, creative learning, creative classes, publications Madrese, Fifth Edition, p. 107.

B. Daffi., Translation: M. Yasaei 2002, encouraged creativity and imagination in children, Tehran: Ghoghnus

Razavian 1999, the city's, Master's thesis, University ..., p. 73 and 78.

Zhan, C., in 2004, the game and the emotions of childhood, London, pp. 146-150.

Sam Khanian, M. R., 2005, creativity and innovation in educational organizations, Tehran: Rasane Takhasosi Seyfollah 2000, educational psychology, learning and training.

Shiei, A., 2012, to prepare the city for children, Tehran: Publication City, Municipality Cultural Organization, p. 4, 5, 19 and 21

S. Tufan, 2006, Children's bower, a thesis for a master's degree, Tabriz Islamic Azad University.

F. Ghasemzadeh., 1991, children and creativity, healthy society magazine, Issue 3, p. 50.

H. Kamelnia S. Haghir,., Design patterns, child-friendly green space in the city (Case Study: Child Friendly City Bam), garden, (12) 6, Winter 2009, page 88-77

Galin, Tumas, introduction to psychology children's drawings, translation Faramarzi, Mohammad Taghi, Tehran, Donyayeno new publishing, printing 
Mohammadi. 87-2007, education center children's creativity, thesis to get a master's degree, Islamic Azad University of Shiraz.

Motlaghzadeh, R., 1999, children's play equipment, Tehran Beautification Organization of Tehran.

Nozaffar F.., Hosseini, B ... M. Bagheri. And H. Azemati., 2007, the role of open spaces in the development and creativity of children, garden, fourth year, fall, and winter 2007-2008, p. 72-.59.

Noghrekar., F. Mozafar. And B. Saleh. And M. Shafaei., 2009, daycare spaces designed based on the relationship between creativity and the idea of architectural traits, Journal of Educational Innovations, (32) 8, pp. 39-59

F. Yaghuti 2009, Mrkzafrynsh intellectual Children's art thesis for the degree of Bachelor of Architecture, Islamic Azad University of Orumiyeh.

Acar, Habibe, Procedia - Social and Behavioral Sciences, Volume 141, 25 August 2014, Pages 846-853.

Bisadi, mona, hosseini, seyed bagher, Future Research Centers: The place of creativity and innovation 2012.

Davies,Dan, Jindal-Snape, Collier, Digby, Alan Howe Volume 8, April 2013, Pages 80-91.

Faizi, Mohsen, Karimi, Amirreza, Azari, Saeid, Design Principles of Residential Spaces to Promote Children's Creativity, Volume 35, 2012, Pages 468-474.

Griffin,B, 1989, Laboratory design guide, Architectect press.

M, Zani, La Convention de l'O.N.U. relative aux droits despersonnes handicapées, Revue de droit international et de droit compare, 2008.

Willy, johan, Inc, 2000, Building type basic for elementary and secondary schools

www.archdaily.com 